\title{
PERBEDAAN TINGKAT PENGETAHUAN TENTANG KEHAMILAN SEHAT DENGAN INDIKATOR KESEHATAN IBU HAMIL YANG MENGIKUTI KELAS IBU HAMIL
}

\author{
Sri Mumpuni Yuniarsih" ${ }^{1 *}$, Anik Indriono², Siwi Sri Widhowati ${ }^{3}$
}

123 Staf Pengajar di Program Studi Keperawatan Universitas Pekalongan. Jl. Sriwijaya No.3 Peklongan 51111, e-mail: unipekalongan@gmail.com

\begin{abstract}
Background: Maternal Mortality Rate (MMR) in Indonesia is still one of the highest in Southeast Asia (ASEAN). World Health Organization (WHO) as the international organization is targeting a decrease in the (MMR) as one of the targets in the achievement of the Millennium Development Goals (MDGs). However, based on the evaluation of part-time Development Plan 2010-2014, the target of reducing maternal mortality rate in Indonesia is still very difficult to achieve. One of the government's efforts to accelerate the decline of maternal mortality rate is a mother class program.

Objective: This study aimed to analyze the achievement of the indicators of maternal health program in comparison with the class of pregnant women who do not attend pregnant women class.

Methods: This research was a quantitative research with cross sectional design that compared the achievement of the nine indicators of the health of pregnant women in the two groups of pregnant women. The variable in this study was a comparison of weight gain, blood pressure, upper arm circumference (MUAC), high fundus, fetal heart rate (FHR), the consumption of iron tablets, hemoglobin levels, antenatal visits, and knowledge about healthy pregnancies. The number of samples in this study were 209 respondents which were divided into groups of 86 respondents in a class of pregnant women and 123 respondents in the non-class group of pregnant women. Chi square and t test was used to analyze the comparison of maternal health indicators achievement advance of two groups of respondents.

Results and Discussion: The results showed that there were significant difference in knowledge about a healthy pregnancy, the consumption of iron tablet and number of antenatal visits. Pregnant women who attended classes had a better knowledge, more Fe tablet consumption and ANC visit. While indicators of weight gain, MUAC, TFU and DJJ of all respondents were within the normal range according to gestational age when the data retrieval. The other indicators such as hemoglobin level, systolic and diastolic blood pressure did not reveal any significant differences between the two groups of respondents.
\end{abstract}

Keywords: Mother class program; maternal health indicators

\section{PENDAHULUAN}

Salah satu masalah pembangunan global adalah kesehatan ibu. Sebanyak sepertiga juta wanita di dunia diperkirakan meninggal setiap tahun akibat kondisi kehamilan. Di Indonesia AKI masih menjadi salah satu yang tertinggi di kawasan Asia Tenggara (ASEAN). World Health Organization (WHO) sebagai organisasi Internasional menargetkan penurunan angka kematian ibu (AKI) sebagai salah satu target pencapaian dalam Millenium Development Goals (MDGs). MDG-s menargetkan penurunan sepertiga rasio $\mathrm{AKI}$ pada tahun 2015 dibandingkan dengan tahun $1990 .^{1}$

Mengacu pada target $\mathrm{WHO}$, pemerintah Indonesia menargetkan AKI turun menjadi 125 per 100.000 kelahiran hidup pada tahun 2010 dan 118 per 100.000 kelahiran hidup pada tahun 2014. Namun, berdasarkan 
evaluasi paruh waktu RPJM 2010-2014, Bappenas (2013) menyatakan bahwa target ini masih sangat sulit dicapai.

Pemerintah Indonesia telah mengupayakan usaha percepatan penurunan AKI melalui peningkatan pengetahuan dan perubahan perilaku ibu dan keluarga. Dengan peningkatan pengetahuan dan perubahan perilaku ini diharapkan kesadaran terhadap pentingnya kesehatan selama kehamilan menjadi meningkat. Program yang diselenggarakan oleh Kementerian Kesehatan untuk mendukung langkah tersebut adalah kelas ibu hamil. ${ }^{2}$

Kelas Ibu Hamil adalah kelompok belajar ibu-ibu hamil dengan umur kehamilan antara 4 minggu s.d. 36 minggu (menjelang persalinan) dengan jumlah peserta maksimal 10 orang. Kegiatan dilakukan secara terjadwal yang dipandu oleh bidan atau tenaga kesehatan yang telah mendapat pelatihan menjadi fasilitator kelas ibu hamil. Di kelas ini ibu bisa berbagi informasi mengenai kesehatan ibu dan anak dan hal lain yang terkait dengan sesama dan juga petugas kesehatan. Paket yang digunakan dalam kelas ibu hamil yaitu Buku KIA, flip chart (lembar balik), pedoman pelaksanaan kelas ibu hamil, pegangan fasilitator kelas ibu hamil dan buku senam ibu hamil. ${ }^{3}$

Salah satu daerah yang sudah mengembangkan kelas ibu hamil di Jawa Tengah adalah Kecamatan Wiradesa Kabupaten Pekalongan. Di bawah pengelolaan Puskesmas Wiradesa, sebanyak
5 desa di Kecamatan Wiradesa telah menerapkan program kelas ibu hamil yang diketuai oleh bidan masing-masing desa. Namun, capaian kerja program ini belum terevaluasi secara terstruktur, termasuk belum diteliti secara ilmiah.

Penelitian ini akan menganalisis pencapaian upaya kesehatan dari program kelas ibu hamil di wilayah kerja Puskesmas Wiradesa Kabupaten Pekalongan. Pencapaian indikator kesehatan ini akan didasarkan pada berbagai indikator kesehatan ibu hamil yang tercantum dalam standar pelayanan antenatal care dari Departemen Kesehatan Indonesia. Dengan demikian, penelitian diharapkan dapat memberikan manfaat dengan cakupan yang luas ke berbagai pihak

\section{BAHAN DAN CARA PENELITIAN}

Rancangan penelitain yang digunakan kuantitatif dengan pendekatan waktu yang digunakan dalam penelitian ini adalah cross sectional dengan jumlah populasi sebanyak 480 ibu hamil dan sampel sebanyak 209 ibu hamil dengan kelompok yang mengikuti kelas ibu hamil sebanyak 86 yang mengikuti kelas ibu hamil dan 123 ibu yang tidak mengikuti kelas ibu hamil. Pengumpul data dalam penelitian ini adalah peneliti sendiri dibantu dengan anggota peneliti dan pengumpul data juga dibantu oleh bidan desa di lokasi penelitian. ${ }^{4,5,6}$

Instrumen yang digunakan dalam penelitian ini berupa berbagai alat ukur di 
antaranya alat ukur panjang berupa meter line, alat ukur berat berupa timbangan injak, alat ukur DJJ berupa fetal doppler, dan alat hitung molekul hemoglobin merupakan alat ukur standar internasional sehingga tidak membutuhkan standarisasi ulang. Sedangkan lembar ceklist digunakan untuk mengukur jumlah konsumsi tablet $\mathrm{Fe}$ dan jumlah kunjungan antenatal. Untuk mengukur pengetahuan ibu digunakan kuesioner evaluasi kelas ibu hamil dari Kemenkes RI, sehingga tidak membutuhkan uji validitas dan reliabilitas. Kuesioner tersebut ada tiga yang terdiri atas kuesioner pertemuan pertama, kedua, dan ketiga. Masing-masing kuesioner terdiri atas 10 item pertanyaan. Kuesioner evaluasi pertemuan pertama menilai tentang perubahan tubuh selama kehamilan, hal-hal yang harus dilakukan ibu selama kehamilan, tenaga kesehatan yang dirujuk, tanda bahaya persalinan, serta persiapan persalinan. Kuesioner evaluasi pertemuan kedua menilai mengenai tanda-tanda persalinan, tenaga penolong persalinan, dukungan suami, seputar nifas, dan KB. Sedangkan kuesioner evaluasi pertemuan ketiga menilai tentang tanda-tanda bayi lahir sehat, ASI eksklusif, tanda bahaya bayi baru lahir, imunisasi, penyakit menular seksual, dan HIV AIDS. ${ }^{3}$

Seluruh responden mengisi kuesioner yang telah disiapkan, kemudian diambil sampel untuk pemeriksaan kadar $\mathrm{Hb}$ setelah itu dilakukan pemeriksaan oleh bidan desa. Jumlah kunjungan ANC dan jumlah konsumsi tablet Fe dilihat dari Buku KIA ibu kemudian didokumentasikan di lembar checklist peneliti. Data dianalisis menggunakan analisis univariat yang mendiskripsikan karakteristik responden seperti usia, status kehamilan, dan usia kehamilan. Sedang analisis bivariat yang digunakan untuk melihat perbedaan beberapa indikator kesehatan ibu tersebut di antaranya menggunakan uji chi square dan uji T test. ${ }^{4,5,6}$

Penelitian ini menggunakan dua kelompok yaitu kelompok yang mengikuti kelas ibu hamil dan kelompok yang tidak mengikuti kelas ibu hamil. Peneliti memilih responden dengan teknik insidental sampling dengan mengumpukan ibu yang mengikuti kelas ibu hamil dan yang tidak mengikuti di masing-masing desa.

\section{HASIL DAN PEMBAHASAN}

Karakteristik responden dalam penelitian dijabarkan dalam 3 variabel yaitu usia, status kehamilan, dan trimester sebagaimana tabel 1 berikut.

Tabel 1. Karakteristik Responden

\begin{tabular}{|c|c|c|c|c|c|}
\hline \multirow[t]{2}{*}{ Variabel } & \multirow[t]{2}{*}{ Kategori } & \multicolumn{2}{|c|}{$\begin{array}{c}\text { Kelas Ibu } \\
\text { Hamil } \\
(\mathrm{N}=86)\end{array}$} & \multicolumn{2}{|c|}{$\begin{array}{c}\text { Non Kelas } \\
\text { Ibu Hamil } \\
(\mathrm{N}=123)\end{array}$} \\
\hline & & $\mathrm{n}$ & $\%$ & $\mathrm{n}$ & $\%$ \\
\hline \multirow[t]{3}{*}{ Usia } & $\begin{array}{l}<20 \\
\text { tahun }\end{array}$ & 3 & $3.5 \%$ & 5 & $4.1 \%$ \\
\hline & $\begin{array}{l}20-35 \\
\text { tahun }\end{array}$ & 74 & $86 \%$ & 99 & $80.5 \%$ \\
\hline & $\begin{array}{l}>35 \\
\text { tahun }\end{array}$ & 9 & $10.5 \%$ & 19 & $15.4 \%$ \\
\hline Status & $\mathrm{Ke}-1$ & 33 & $38.4 \%$ & 44 & $35.8 \%$ \\
\hline \multirow[t]{4}{*}{ Kehamilan } & $\mathrm{Ke}-2$ & 28 & $32.6 \%$ & 43 & $35 \%$ \\
\hline & $\mathrm{Ke}-3$ & 19 & $22.1 \%$ & 20 & $16.3 \%$ \\
\hline & $\mathrm{Ke}-4$ & 6 & $7 \%$ & 15 & $12.2 \%$ \\
\hline & $\mathrm{Ke}-5$ & 0 & $0 \%$ & 1 & $0.8 \%$ \\
\hline \multirow[t]{3}{*}{ Trimester } & I & 3 & $3.5 \%$ & 36 & $29.3 \%$ \\
\hline & II & 21 & $24.4 \%$ & 58 & $47.2 \%$ \\
\hline & III & 62 & $72.1 \%$ & 29 & $23.6 \%$ \\
\hline
\end{tabular}


Sebagian besar responden berada pada usia reproduksi sehat untuk kehamilan (20-35 tahun. Sebagian besar adalah ibu dengan kehamilan pertama (38.2\%) dan kedua (32.6\%). Dilihat dari usia kehamilan, $72.1 \%$ peserta kelas ibu hamil adalah ibu dengan kehamilan trimester ketiga

Tabel 2. Perbandingan Pencapaian Indikator Kesehatan Ibu Hamil pada Kelas Ibu Hamil dan non Kelas Ibu Hamil dengan Uji Chi Square

\begin{tabular}{|c|c|c|c|c|c|c|}
\hline Indikator & Kategori & $\begin{array}{l}\mathrm{Ke} \\
\mathrm{Ha}\end{array}$ & Ibu & $\begin{array}{l}\text { Non } \\
\text { Kela } \\
\text { Ham }\end{array}$ & Ibu & $\begin{array}{l}\mathbf{P} \\
\text { Value }\end{array}$ \\
\hline & & $\mathbf{f}$ & $\%$ & $f$ & $\%$ & \\
\hline Tekanan & Normal & 71 & 82.6 & 95 & 77.2 & 0.349 \\
\hline $\begin{array}{l}\text { darah } \\
\text { sistolik }\end{array}$ & Tinggi & 15 & 17.4 & 28 & 22.8 & \\
\hline Tekanan & Normal & 84 & 97.7 & 122 & 99.2 & 0.366 \\
\hline $\begin{array}{l}\text { Darah } \\
\text { Diastolik }\end{array}$ & Tinggi & 2 & 2.3 & 1 & 0.8 & \\
\hline Kadar $\mathrm{Hb}$ & Normal & 41 & 47.7 & 67 & 54.5 & 0.333 \\
\hline & Rendah & 45 & 52.3 & 56 & 45.5 & \\
\hline Pengetahu & Kurang & 35 & 40.7 & 97 & 78.9 & 0.000 \\
\hline an I & Baik & 51 & 59.3 & 26 & 21.1 & \\
\hline Pengetahu & Kurang & 62 & 72.1 & 118 & 86.1 & 0.000 \\
\hline an II & Baik & 24 & 27.9 & 5 & 4.1 & \\
\hline Pengetahu & Kurang & 11 & 12.8 & 46 & 37.4 & 0.000 \\
\hline an III & Baik & 75 & 87.2 & 77 & 62.6 & \\
\hline
\end{tabular}

pencapaian indikator kesehatan ibu hamil pada variabel-variabel dengan data kategorik. Hasil uji chi square menunjukkan tidak adanya perbedaan yang signifikan antara responden kelas ibu hamil dengan non kelas ibu hamil pada variabel tekanan darah sistolik, tekanan darah diastolik, dan kadar $\mathrm{Hb}$, yang ditunjukkan oleh $p$ value lebih dari 0.05 . Sedangkan pada variabel pengetahuan ibu hamil tentang kehamilan sehat terdapat perbedaan yang signifikan antara kelas ibu hamil dengan non kelas ibu hamil, baik pengetahuan di trimester pertama, kedua maupun ketiga. Responden kelas ibu hamil cenderung memiliki pengetahuan yang lebih baik daripada responden non kelas ibu hamil, terutama pada pengetahuan di trimester pertama, yaitu $59.3 \%$ responden kelas ibu hamil memiliki pengetahuan baik sedangkan hanya $21.1 \%$ responden non kelas ibu hamil yang memiliki pengetahuan baik. Meskipun berbeda secara signifikan, tetapi responden dari kedua kelas cenderung mempunyai pengetahuan yang kurang pada kehamilan sehat di trimester kedua dan ketiga.

Dua indikator lain (konsumsi tablet zat besi dan kunjungan antenatal) dianalisa dengan uji $t$-test karena kedua indikator ini disajikan dengan data numerik dalam tabel 3 berikut ini.

Tabel 3. Perbandingan Pencapaian Indikator Kesehatan Ibu Hamil pada Kelas Ibu Hamil dan non Kelas Ibu Hamil dengan Uji t-Test

\begin{tabular}{|c|c|c|c|c|c|}
\hline \multirow[t]{2}{*}{ Indikator } & $\begin{array}{l}\text { Kelas } \\
\text { Hamil }\end{array}$ & Ibu & $\begin{array}{l}\text { Non } \\
\text { lbu H }\end{array}$ & $\begin{array}{l}\text { Kelas } \\
\text { Imil }\end{array}$ & \multirow{2}{*}{$\begin{array}{l}\text { t-Test } \\
P \\
\text { Value }\end{array}$} \\
\hline & $\begin{array}{l}\text { Rata } \\
\text {-rata }\end{array}$ & SD & $\begin{array}{l}\text { Rata } \\
- \\
\text { Rata }\end{array}$ & SD & \\
\hline $\begin{array}{l}\text { Konsumsi } \\
\text { Tablet Fe }\end{array}$ & $\begin{array}{l}44.5 \\
3\end{array}$ & 23.993 & $\begin{array}{l}31.1 \\
4\end{array}$ & 19.802 & 0.000 \\
\hline $\begin{array}{l}\text { Kunjungan } \\
\text { Antenatal }\end{array}$ & 5.80 & 2.320 & 3.71 & 2.632 & 0.000 \\
\hline
\end{tabular}

Tabel 3 menunjukkan adanya perbedaan yang signifikan antara responden kelas ibu hamil dengan non kelas ibu hamil dalam mengkonsumsi tablet $\mathrm{Fe}$ dan melakukan kunjungan antenatal. Responden kelas ibu hamil cenderung mengonsumsi tablet $\mathrm{Fe}$ 
lebih banyak daripada responden non kelas ibu hamil. Angka kunjungan antenatal pada responden kelas ibu hamil juga lebih tinggi (rata-rata 5.8 kunjungan) dibandingkan kelas non ibu hamil (rata-rata 3.71 kunjungan).

Tabel 1 memberikan gambaran bahwa sebagian besar peserta kelas ibu hamil adalah ibu dengan kehamilan pertama dan kedua. Hal ini menunjukkan bahwa ibu dengan kehamilan pertama atau kedua adalah kelompok yang paling membutuhkan kelas ibu hamil. Kelompok ibu ini dianggap masih kurang pengetahuan dan pengalaman dalam hal kehamilan maupun persiapan persalinan, sehingga kelompok ini lebih membutuhkan program kelas ibu hamil dibanding kelompok ibu yang lain.

Namun, kelas ibu hamil cenderung diikuti oleh ibu hamil yang sudah menginjak trimester ketiga. Padahal pedoman pelaksanaan kelas ibu hamil menyebutkan bahwa peserta kelas ibu hamil sebaiknya ibu hamil pada umur kehamilan 4 s.d. 36 minggu. Hal ini berhubungan dengan materi yang disampaikan dalam kelas ibu hamil. Materi pertemuan pertama kelas ibu hamil membahas tentang perubahan tubuh selama kehamilan dan cara mengatasi keluhankeluhan selama kehamilan. Materi ini sebaiknya diikuti oleh kelompok ibu di awal kehamilan.

Pembahasan ini akan mendiskusikan mengenai pencapaian beberapa indikator kesehatan ibu hamil antara yang mengikuti kelas ibu hamil dengan yang tidak mengikuti kelas ibu hamil. Secara garis besar terdapat indikator yang berbeda secara signifikan, namun ada pula yang tidak berbeda secara signifikan. Dari hasil penelitian ini juga terdapat beberapa indikator yang tidak dapat dibandingkan karena dari kedua kelompok memiliki hasil $100 \%$ sama atau dalam kondisi normal secara keseluruhan. Berikut akan dibahas secara lebih detail.

Dalam penelitian ini terdapat enam indikator yang setelah dilakukan uji statistik tidak terdapat perbedaan yang signifikan, indikator tersebut adalah; pertambahan BB, LiLA, TFU, DJJ, kadar $\mathrm{Hb}$, dan tekanan darah. semua responden berada dalam rentang normal. Pertambahan BB sudah sesuai dengan usia, LiLA secara keseluruhan di atas $23.5 \mathrm{~cm}$, TFU juga sudah sesuai dengan usia kehamilan, dan DJJ berada dalam rentang normal antara 120-160 x/ menit.

Kenaikan berat badan ibu hamil dapat digunakan sebagai indeks untuk menentukan status gizi ibu hamil, karena terdapat kesamaan dalam jumlah kenaikan berat badan saat hamil pada semua ibu hamil. Rata-rata total pertambahan berat badan ibu hamil berkisar $10-15 \mathrm{~kg}$ yaitu $1 \mathrm{~kg}$ pada trimester I dan selebihnya pada trimester II dan III. Mulai trimester II sampai III rata-rata pertambahan berat badan adalah 0,3-0,7 kg /minggu.Bertambahnya berat badan sesuai, minimal $8 \mathrm{~kg}$ selama kehamilan $(1 \mathrm{~kg}$ tiap bulan). ${ }^{7}$ Faktor-faktor yang memengaruhi peningkatan berat badan ibu hamil sendiri 
adalah oedema, proses metabolisme, pola makan, merokok, muntah, atau diare. ${ }^{8}$

Tidak adanya perbedaan pertambahan berat badan antara yang mengikuti kelas ibu hamil dengan tidak mengikuti kelas ibu hamil dimungkinkan karena responden di antara dua kelompok memiliki kondisi yang hampir sama. Misalnya usia ibu hamil di kedua kelompok berada dalam rentang usia produktif, di antara kedua kelompok juga tidak tercatat memiliki penyakit tertentu yang menyebabkan gangguan permasalahan gizi.

Lingkar lengan atas merupakan salah satu alat ukur yang digunakan pada ibu hamil maupun wanita usia subur (WUS) untuk menilai status gizi, sehingga dapat diketahui komplikasi selama kehamilan. ${ }^{9}$ Pada penelitian ini juga tidak ada perbedaan yang bermakna antara responden yang ikut kelas ibu hamil dengan yang tidak ikut kelas ibu hamil, karena dari kedua kelompok memang tidak ada yang mengalami permasalahan gizi.

Pengukuran tinggi fundus uteri mulai dari batas atas symfisis dan disesuaikan dengan hari pertama haid terakhir. Tinggi fundus uteri diukur pada kehamilan $>12$ minggu karena pada usia kehamilan ini uterus dapat diraba dari dinding perut dan untuk kehamilan $>24$ minggu dianjurkan mengukur dengan pita meter. Tinggi fundus uteri dapat menentukan ukuran kehamilan. Bila tinggi fundus kurang dari perhitungan umur kehamilan mungkin terdapat gangguan pertumbuhan janin, dan sebaliknya mungkin terdapat gemeli, hidramnion atau molahidatidosa. ${ }^{10}$ Responden dalam penelitian ini memiliki Ukuran TFU yang sesuai dengan usia kehamilan. Denyut jantung janin pada responden ini juga semua dalam kondisi normal hal ini dumungkinkan karena seluruh responden minimal telah melakukan kunjungan pertama (K1). Jika ibu hamil minimal telah melakukan kunjungan ANC sekali saja dimungkinkan ibu hamil telah mendapatkan informasi mengenai kehamilan sehat, hal-hal apa saja yang harus dilakukan selama kehamilan.

Kadar $\mathrm{Hb}$ merupakan salah satu indikator untuk menilai status anemia atau tidak pada ibu hamil. Kadar Haemoglobin darah ini dapat dipengaruhi oleh beberapa faktor yaitu kecukupan dan metabolisme besi dalam tubuh. ${ }^{11}$ Penelitian ini menunjukkan tidak ada perbedaan yang signifikan dalam kadar $\mathrm{Hb}$ antara yang ikut kelas ibu hamil dengan yang tidak ikut. Begitu pula dalam indikator tekanan darah, tekanan darah pada ibu hamil terutama dipengaruhi oleh penyakit dasar yang dialami ibu dan juga faktor psikologis. Responden dalam penelitian ini sebagian besar tidak memiliki penyakit penyerta.

Kelas ibu hamil merupakan sarana untuk belajar bersama tentang kesehatan bagi ibu hamil, dalam bentuk tatap muka dalam kelompok yang bertujuan meningkatkan pengetahuan dan keterampilan ibu-ibu mengenai kehamilan, persalinan, perawatan nifas dan perawatan bayi baru lahir, mitos, 
penyakit menular, dan akte kelahiran. ${ }^{12}$ Hasil penelitian ini menunjukkan bahwa kelas ibu hamil secara signifikan dapat meningkatkan konsumsi tablet Fe, jumlah kunjungan ANC, dan tingkat pengetahuan ibu mengenai kesehatan ibu hamil. Peningkatan konsumsi tablet $\mathrm{Fe}$ seiringan dengan peningkatan kunjungan ANC karena saat ibu berkunjung pada saat itu pula ibu mendapat tambahan tablet Fe. Peningkatan pengetahuan ibu hamil melalui program kelas ibu hamil ini sesuai dengan hasil penelitian di tempat lain. Hasil penelitian yang dilakukan oleh Japan International Cooperation Agency (JICA) bekerja sama dengan Departemen Kesehatan Republik Indonesia pada tahun 2008 di daerah Nusa Tenggara Barat menyatakan adanya peningkatan pengetahuan, sikap, dan perilaku positif dalam menghadapi kehamilan, persalinan, dan masa nifas pada ibu hamil yang mengikuti kelas antenatal. Sebuah penelitian yang dilakukan oleh Ariyani dkkdi wilayah Kota Denpasar, Gianyar dan Bandung juga menyatakan bahwa kelas antenatal secara signifikan meningkatkan pengetahuan ibu hamil. ${ }^{12}$

Walaupun kelas ibu hamil dapat meningkatkan pengetahuan ibu, akan tetapi program ini belum mencapai target indikator kesehatan ibu hamil yang lainnya. Hal ini menunjukkan bahwa kelas ibu hamil belum bisa menjangkau ranah lanjut dari pengetahuan, yaitu sikap dan perilaku, sehingga perlu diadakan peninjauan atau penelitian selanjutnya mengenai proses pelaksanaan kelas ibu hamil.

\section{KESIMPULAN}

Penelitian ini menunjukkan bahwa hanya variabel pengetahuan, kunjungan ANC, dan jumlah tablet $\mathrm{Fe}$ yang dikonsumsi ibu hamil. Hal ini dimungkinkan program kelas ibu hamil belum bisa memberikan pengaruh yang optimal di beberapa variabel yang lain akibat kegiatan kelas ibu hamil hanya mampu memberikan pengaruh ke ranah kognitif. Perilaku individu dipengaruhi oleh banyak faktor sehingga perlu kajian yang lebih mendalam mengenai proses pelaksanaan program kelas ibu hamil

\section{KEPUSTAKAAN}

1. World Health Organisation. Trends in maternal mortality: 1990 to 2008 . Estimates developed by WHO, UNICEF, UNFPA and the World Bank Geneva . 2010. Available from: URL: whqlibdoc.who.int/publications/2010/978 9241500265_eng.pdf

2. Kemenkes,. Kelas lbu Hamil di Puskesmas Jembatan Kembar, Lombok Berat, NTB. 2012. Available from: URL: http://www.kesehatanibu.depkes.go.id/ar chives/438\#more-438, diakses pada tanggal 28 April 2014

3. Kemenkes RI. Pedoman Pelaksanaan Kelas Ibu Hamil. 2011. Available from: URL:

https://libportal.jica.go.jp/library/Archive/l 
ndonesia/232i.pdf

4. Notoatmodjo, S. Metodologi Penelitian Kesehatan. 2010. Jakarta: Rineka Cipta, hlm:130.

5. Polit, D, F., Beck,C,T., \& Hungler, B, P. Essentialof nursing research: Method appraisal and utilization.6th ed. 2006. Philadelphia: Lippincott. Williams \& Wilkins.

6. Saryono. .Metodologi penelitian kesehatan: penuntun praktis bagi pemula. 2011. Yogyakarta: Penerbit buku kesehatan Mitra Cendikia.

7. Kemenkes RI, 2013. Buku Saku Pelayanan Kesehatan lbu Di Fasilitas Kesehatan Dasar Dan Rujukan. Diakses dari: http://www.searo.who.int/indonesia/docu ments/976-602-235-265-5-buku-sakupelayanan-kesehatan-ibu.pdf?ua=1

8. Salmah (2006). Asuhan Kebidana Antenatal. EGC. Jakarta : 61.

9. Supariasa, I. D. N. Penilaian Status Gizi. 2002. Jakarta: EGC

10. Depkes RI, Pedoman Pelayanan Antenatal. 2007. Direktorat Jenderal Kesehatan Keluarga

11. Zarianis. 2006. Efek Suplementasi BesiVitamin C Dan Vitamin C Terhadap Kadar Hemoglobin Anak Sekolah Dasar Yang Anemia Di Kecamatan Sayung Kabupaten Demak. Available from: URL: http://eprints.undip.ac.id/15967/1/Zarianis .pdf

12. Ariyani, Nw dkk. Pelaksanaan kelas anternatal terhadap perilaku ibu hamil. Jurnal Skala Husada Volume 9 Nomor 1 April 2012: 10-15. Available from: URL: https://libportal.jica.go.jp/library/Archive/l ndonesia/232i.pdf 